\title{
Elderly caregivers of the elderly: frailty, loneliness and depressive symptoms
}

\author{
Idosos cuidadores de idosos: fragilidade, solidão e sintomas depressivos \\ Ancianos cuidadores de ancianos: fragilidad, solidon y sintomas depresivos
}

Ariene Angelini dos Santos-Orlandi'
ORCID: 0000-0002-3112-495X
Allan Gustavo Brigola'
ORCID: 0000-0003-0265-4940

Ana Carolina Ottaviani ' ORCID: 0000-0003-4037-4587

Bruna Moretti Luchesi ' ORCID: 0000-0002-0508-0818

Érica Nestor Souza' ORCID: 0000-0002-7952-7643

Fernanda Gomez de Moura' ORCID: 0000-0002-5195-2146

Juliana de Fátima Zacarin' ORCID: 0000-0001-5053-0868

Mariélli Terassi' ORCID: 0000-0002-8933-3519

Nathalia Alves de Oliveira' ORCID: 0000-0003-1665-8109

Sofia Cristina lost Pavarini ' ORCID: 0000-0001-9359-8600

'Universidade Federal de São Carlos. São Carlos, São Paulo, Brazil.

How to cite this article: Santos-Orlandi AA, Brigolla AG, Ottaviani AC, Luchesi BM, Souza EM, Moura FG, et al. Elderly caregivers of the elderly: frailty, loneliness and depressive symptoms. Rev Bras Enferm. 2019;72(Suppl 2):88-96. doi: http://dx.doi.org/10.1590/0034-7167-2018-0137

\section{Corresponding Author:}

Ariene Angelini dos Santos-Orlandi E-mail: arieneangelini@yahoo.com.br

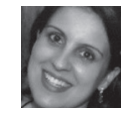

Submission: 03-12-2018

Approval: 07-12-2018

\section{ABSTRACT}

Objective: to investigate the association between frailty, loneliness and depressive symptoms of elderly caregivers. Method: a cross - sectional study carried out with 341 elderly caregivers enrolled in Family Health Units of a city in the countryside of São Paulo State. The interviews were domiciliary and included questionnaire for characterization of the caregiver, Fried's frailty phenotype, family APGAR (family functionality), Geriatric Depression Scale (depressive symptoms) and item 3 of the Herth Hope Scale (loneliness). Logistic regression was used to analyze the association between depressive symptoms and solitude (independent variables), and frailty and pre-frailty (dependent variables). Results: there was an association between frailty, loneliness and depressive symptoms. Elderly caregivers had increased odds of $158 \%$ presenting pre-frailty, and $360 \%$ of frailty. Elderly caregivers with depressive symptoms had an increased chance of $242 \%$ of presenting fragility. Conclusion: elderly and lonely caregivers with depressive symptoms are more likely to be frail and pre-frail.

Descriptors: Caregivers; Depression; Frail Elderly; Loneliness; Geriatric Nursing.

\section{RESUMO}

Objetivo: investigar a associação entre fragilidade, solidão e sintomas depressivos de idosos que cuidam de idosos. Método: estudo transversal, realizado com 341 idosos cuidadores cadastrados em Unidades de Saúde da Família de um município do interior paulista. As entrevistas foram domiciliares e incluíram questionário para caracterização do cuidador, fenótipo de fragilidade de Fried, APGAR de família (funcionalidade familiar), Escala de Depressão Geriátrica (sintomas depressivos) e item 3 da Escala de Esperança de Herth (solidão). A regressão logística foi utilizada para analisar a associação entre sintomas depressivos e solidão (variáveis independentes), e fragilidade e pré-fragilidade (variáveis dependentes). Resultados: houve associação entre fragilidade, solidão e sintomas depressivos. Idosos cuidadores solitários tiveram chances aumentadas em $158 \%$ de apresentar pré-fragilidade, e $360 \%$ de fragilidade. Idosos cuidadores com sintomas depressivos tiveram chances aumentadas em $242 \%$ de apresentar fragilidade. Conclusão: idosos cuidadores solitários e que apresentam sintomas depressivos têm mais chances de serem frágeis e pré-frágeis.

Descritores: Cuidadores; Depressão; Idoso Fragilizado; Solidão; Enfermagem Geriátrica.

\section{RESUMEN}

Objetivo: investigar la asociación entre fragilidad, soledad y síntomas depresivos de ancianos que cuidan de ancianos. Método: estudio transversal, realizado con 341 ancianos cuidadores catastrados en Unidades de Salud de la Familia de un municipio del interior paulista. Las entrevistas fueron domiciliarias e incluyeron cuestionario para caracterización del cuidador, fenotipo de fragilidad de Fried, APGAR de familia (funcionalidad familiar), Escala de Depresión Geriátrica (síntomas depresivos) y ítem 3 de la Escala de Esperanza de Herth (soledad). La regresión logística fue utilizada para analizar la asociación entre síntomas depresivos y soledad (variables independientes), y fragilidad y pre-fragilidad (variables dependientes). Resultados: hubo asociación entre fragilidad, soledad y síntomas depresivos. Los ancianos cuidadores solitarios tuvieron posibilidades aumentadas en el $158 \%$ de tener pre-fragilidad, y el $360 \%$ de fragilidad. Los ancianos cuidadores con síntomas depresivos tuvieron posibilidades aumentadas en un $242 \%$ de tener fragilidad. Conclusión: los ancianos cuidadores solitarios y que presentan síntomas depresivos tienen más probabilidades de ser frágiles y pre-frágiles. Descriptores: Cuidadores; Depresión; Anciano Frágil; Soledad; Enfermería Geriátrica. 


\section{INTRODUCTION}

The increase in life expectancy of the population, combined with the high prevalence of chronic diseases and non-communicable diseases, can cause many older people to present more complex health needs, as well as a decline in their functional performance, making them dependent on a caregiver $r^{(1-2)}$. The number of elderly people in need of care worldwide is increasing ${ }^{(2)}$.

In Brazil, it is a subject of great relevance, due to the prevalence of informal care, new family arrangements and insufficient care to existing care demands and their predicted injuries in the near future ${ }^{(3)}$. According to the Global Strategy and Action Plan on Ageing and Health proposed by the World Health Organization (WHO), changes should be made in the health system to ensure access to services focused on the needs and rights of the elderly, seeking a personalized and integral service. In this sense, one of the main actions is the offer of support to caregivers of these elderly people ${ }^{(2)}$.

We are living today in a context in which a high prevalence of elderly people is observed taking care of other older people more dependent ${ }^{(4)}$. When the caregiver is also an elderly person, health professionals and, in particular, the nursing team should be attentive to the health conditions of this elderly caregiver.

Recent research with family caregivers reveals that experiences of burden, stress, loneliness ${ }^{(5)}$, depressive symptoms and physical health impairment ${ }^{(6)}$ are common in this context. These feelings are understandable, since many of them do not receive help from other people to carry out the task of caring, suffering a reduction of time for themselves, besides isolating themselves socially ${ }^{(5,7)}$.

Loneliness is an experience characterized by a poor network of personal relationships that can influence health and well-being, being an important challenge that caregivers face and is associated with premature morbidity and mortality ${ }^{(8-9)}$. It is necessary to invest in community groups, self-help, elderly organizations, for example, in order to involve them socially, avoiding the risk of isolation and loneliness ${ }^{(2)}$.

Researchers say that loneliness can have negative health outcomes and is considered a risk factor for cognitive decline ${ }^{(10)}$, development of pain, fatigue, and depression ${ }^{(11)}$. A cross-sectional study was conducted in Amsterdam with 2,878 people aged 55-85 years to determine whether loneliness associated with depression was associated with mortality. As a result, they found that loneliness and depression are important predictors of early death in the elderly ${ }^{(8)}$. It is noteworthy that, together with the feeling of loneliness, depressive symptoms also become very present in the routine of the caregiver. The combination of both can lead to higher levels of physical vulnerability ${ }^{(12)}$. Individuals with lonely and depressive symptoms may present inappetence, chronic malnutrition and physical inactivity, which increases the risks for the development of frailty ${ }^{(13)}$. Cross-sectional studies with older adults show that frailty may predict the development of depressive symptoms over the years ${ }^{(14-15)}$.

Currently, there are several studies related to the frailty syndrome in the elderly. When it comes to elderly caregivers, data are still scarce ${ }^{(16-17)}$. In Brazil, a study carried out with 50 elderly caregivers of elderly people attended in an outpatient clinic identified that there is an association between depressive symptoms and frailty. However, the authors themselves point out that due to the small number of participants, it was not possible to establish a broader relationship among the variables ${ }^{(17)}$.

The Global Strategy and Action Plan on Ageing and Health professionals in relation to frailty ${ }^{(2)}$. In addition, the National Elderly Health Policy states the need to assess local resources to deal with the frail elderly, in order to facilitate home care. A caregiver in the family environment should be included as a partner of the care team, seeking to foster a network of solidarity with the frail elderly and their caregiver ${ }^{(18)}$, which reinforces the need for evaluation and follow-up of these variables, including relatives arrangements.

The present study is based on the presented scenario that contemplates the aging population, the demand for care, the elderly caregiver and the variables loneliness, depressive symptoms and frailty. Considering that research on the relationship between frailty, loneliness and depressive symptoms are scarce in Brazil and worldwide, especially when it comes to elderly caregivers, there is justification for this study. It is hoped that the results can help fill this gap in the scientific literature by subsidizing health services in planning quality care for older caregivers.

\section{OBJECTIVE}

To investigate the association between frailty, loneliness and depressive symptoms of elderly caregivers.

\section{METHOD}

\section{Ethical aspects}

All the ethical aspects that govern researches with human beings were observed and respected, according to Resolution 466/2012 regulated by the Brazilian Health Board (Conselho Nacional de Saúde). The research project was approved by the Human Research Ethics Committee of the Universidade Federal de São Carlos. All participants signed the Free and Informed Consent Form before the interview.

\section{Design, place of study and period}

Cross-sectional and quantitative study, with data from the research titled "Variáveis associadas à cognição de idosos cuidadores" developed by the research group "Health and Aging" of the Universidade Federal de São Carlos. The data collection occurred in the period from April to November 2014.

\section{Sample, inclusion and exclusion criteria}

Older caregivers enrolled in all Family Health Units (FHU) of a city in the countryside of São Paulo State participated in the study. The inclusion criteria were: to be 60 years of age or older; be enrolled in an FHU of the municipality; be primary caregiver; and reside in the same household as a 60-year-old or older dependent for at least one basic activity of daily living (BADL) or instrumental activity of daily living (IADL), assessed by the Katz Index ${ }^{(19)}$ and Scale of Lawton and Brody ${ }^{(20)}$ respectively. Exclusion criteria were defined as: all the elderly in the household score 
as independent for BADL and IADL; death of one of the elderly in the residence; address change; and not be found after three visits on different days and times.

The sample was selected from a total of 594 households, where two or more elderly people lived. These households were identified through lists provided by Community Health Agents of each microarea of the FHU. All households were visited, 26 were excluded due to the death of one of the elderly, 28 due to a change of address, 69 because they were not found in their homes after three attempts and 84 because they refused to participate in the study. The elderly was assessed in relation to BADL and IADL and 36 were excluded, since both were independent for the same, totaling 351 elderly caregivers assessed. Of these, 10 were excluded because they did not present a complete evaluation of the variables used for data analysis, resulting in the final sample of 341 elderly caregivers.

\section{Study protocol}

Data collection was performed through previously scheduled home interviews, by trained researchers. The interviews took place in a single session, lasting approximately one hour and thirty minutes. The variables of interest were investigated using the following measures:

- Sociodemographic and health characterization: gender (female and male), age (years), schooling (years), marital status (married, single, divorced or widowed), family income (minimum wages), number of self-reported morbidities presence of two or more were characterized as multimorbidity), number of drugs in use (use of five or more was characterized as polypharmacy).

- Characterization of care context: degree of relationship with care dependent elderly (spouse, child, son-in-law, sibling, other), number of people living in the household, length of care (years), hours of care day care, and help (material, emotional, religious groups, health care and social services).

- Frailty: assessed according to the five-component phenotype - unintentional weight loss (assessed by the question "In the last 12 months did you think you lost weight without a diet?"With an affirmative answer in case of loss greater than $4.5 \mathrm{~kg}$ or $5 \%$ by weight), fatigue (assessed by two questions from the Center for Epidemiological Studies - Depression, CES-D: 1) How often in the last week did you feel that everything you did required a lot of effort? and 2) How often in the last week did you feel that you could not get things going?" There was an affirmative answer in the case of "always" or "most of the time" in at least one question; low palmar grip strength (measured by the average of three consecutive gripping force measurements of the dominant hand in Kgf using a Jamar type hydraulic dynamometer, Model SH5001, manufactured by SAEHAN ${ }^{\circ}$, Lafayette, Illinois, USA, with the elderly being in the lowest adjusted quintile by gender and Body Mass Index (BMI) scored affirmatively); slowness of gait (measured by the average of three measures of the time spent in seconds to walk 4.6 meters in a straight line in the plane, in a usual step, being allowed the use of walking stick or walker. In order to allow acceleration and deceleration, two meters before and two meters after the course were added, totaling $8.6 \mathrm{~m}$ of walking, with the $20 \%$ slower, according to gender and mean height, which were affirmed); and low level of physical activity (indicated by the affirmative answer to the question "Do you think you do less physical activity than 12 months ago?"). The presence of three or more components of the phenotype characterize the person as frail; of one or two criteria as pre-frail and none as non-frail(21).

- Family function: assessed by family $\operatorname{APGAR}^{(22)}$ through five questions regarding the individual's satisfaction with adaptation, partnership, growth, affection and problem solving ability. Scores may range from one to 20 , one to eight - high family dysfunction, nine to 12 - moderate family dysfunction and 13 points or more - good family function.

- Depressive symptoms: assessed by the Geriatric Depression Scale, version of 15 items ${ }^{(23)}$. At the end, the score obtained is summed. For this study, it was considered zero to four points - no depressive symptoms; five to 15 points - with depressive symptoms ${ }^{(24)}$.

- Loneliness: assessed by item 3 of Herth's Hope Scale ("I feel very alone")(25) with possibility of response "I completely disagree, disagree, agree and agree completely". The feeling of loneliness was defined for the caregivers who responded I agree and agree completely. Absence of feeling of loneliness (Strongly Disagree and Disagree) was reference category.

\section{Analysis of results; and statistics}

The data were typed and validated with double entry and blinded in the software Epidata 3.1 and exported to software Statistical Package for the Social Sciences (SPSS for Windows), version 21.0 (IBM Inc., Chicago, IL, USA).

Sociodemographic, health and care context information were reported on average and Confidence Interval $(95 \% \mathrm{Cl})$ for the total sample (Tables 1-2).

Multinominal regression for pre-frailty and frailty was performed separately, being the non-frail category, reference. Firstly, the feeling of loneliness and the indication of depressive symptoms were individually inserted into a model independent of the other covariables. Multiple regression models were constructed including the insertion of the feeling of loneliness and the indication of depressive symptoms and controlled by age, gender, schooling, income, number of children, family function and multimorbity, and polypharmacy.

In addition, the Pearson's Correlation Coefficient ( $r$ ) was used to test correlations between the covariates and the frailty variable in its continuous manner. The chi-square test was used to test associations between loneliness variables and depressive symptoms and co-variables. Associations at the $\mathrm{p} \leq 0.05$ level were significant.

As hypotheses of the study, it is believed that there is an association between frailty and advanced age, low schooling, low income, polypharmacy, multimorbity, family dysfunction, loneliness and depressive symptoms. 


\section{RESULTS}

Sociodemographic and health characteristics of elderly caregivers are described below, in Table 1.

The majority of elderly caregivers were female (76.8\%), were between 60 and 69 years old (57.8\%), had one to four years of schooling (62.8\%) and were married (90.3\%). It presented, on average, 2,303.21 reais (reais is the Brazilian currency) family income, 5.44 morbidities and 3.13 medications in use (Table 1 ).

Table 2 presents information about the family context and care in which these elderly caregivers were inserted.

Elderly caregivers presented good family function (85.0\%), caring for their spouses $(85.0 \%)$, exercising care for more than 10 years $(50.7 \%)$ and for up to eight hours a day $(74.5 \% \%)$ (Table 2 ).

Table 3 shows the profile of elderly caregivers in relation to frailty, loneliness and depressive symptoms.

There was a predominance of pre-frail elderly caregivers (56.3\%). Regarding the frailty criteria, $54.3 \%$ of the elderly caregivers scored for physical inactivity, followed by the weakness component (34.6\%). The majority of elderly caregivers did not present feeling of loneliness (76.2\%), nor did they present depressive symptoms (70.4\%) (Table 3).

Table 4 presents the results of the univariate regression between frailty, loneliness and depressive symptoms of elderly caregivers.

Elderly caregivers who presented feelings of loneliness were 2.33 times more likely to be pre-frail and 2.43 times more likely to be frail when compared to caregivers without feelings of loneliness, regardless of other factors.

Elderly caregivers with depressive symptoms were 2.40 times more likely to be pre-frail and 5.65 times more likely to be frail compared to caregivers without depressive symptoms, regardless of other factors (Table 4 ).

Table 5 presents the results of the multiple regression between frailty, loneliness and depressive symptoms of elderly caregivers.

Elderly caregivers had increased odds of $158 \%$ of pre-frailty and $360 \%$ of frailty compared to non-loners (model controlled by gender, age, schooling, depressive symptoms, family income, number of children, family function, multimorbity, and polypharmacy).

Elderly caregivers with depressive symptoms had an increased $242 \%$ chance of being frail when compared to caregivers without depressive symptoms (model controlled by gender, age, schooling, loneliness, family income, number of children, family function, multimorbity and polypharmacy).

Age and polypharmacy variables were also associated with frailty. Elderly caregivers older than 70 years were $162 \%$ more likely to be pre-frail and $289 \%$ frail. Those elderly caregivers who used polypharmacy presented increased chances in 369\% of being frail.
Table 1 - Sociodemographic and health characterization of elderly caregivers, São Carlos, São Paulo, Brazil, 2014

\begin{tabular}{|c|c|c|c|c|}
\hline Variables & Categories & $\%$ & Mean & $(95 \% \mathrm{CI})$ \\
\hline \multirow[t]{2}{*}{ Gender } & Female & 76.8 & & \\
\hline & Male & 23.2 & & \\
\hline \multirow[t]{4}{*}{ Age (years) } & & & 69.61 & (68.8-70.3) \\
\hline & $60-69$ years & 57.8 & & \\
\hline & 70-79 years & 30.8 & & \\
\hline & 80 years or more & 11.4 & & \\
\hline \multirow[t]{5}{*}{ Schooling (years) } & & & 3.81 & $(3.4-4.1)$ \\
\hline & 9 years or more & 9.7 & & \\
\hline & $5-8$ years & 9.7 & & \\
\hline & $1-4$ years & 62.8 & & \\
\hline & No schooling & 17.8 & & \\
\hline \multirow[t]{4}{*}{ Marital status } & Married & 90.3 & & \\
\hline & Not married & 4.1 & & \\
\hline & Divorced & 1.8 & & \\
\hline & Widowed & 3.8 & & \\
\hline Family Income (reais) & & & 2303.21 & (2128.69-2477.73) \\
\hline \multirow[t]{2}{*}{ Morbidity } & & & 5.44 & $(5.1-5.7)$ \\
\hline & Multimorbidity & 90.3 & & \\
\hline \multirow[t]{2}{*}{ Medications in use } & & & 3.13 & $(2.8-3.3)$ \\
\hline & Polipharmacy & 24.9 & & \\
\hline
\end{tabular}

Note: $95 \%$ Cl: $95 \%$ Confidence Interval; $n=341$

Table 2 - Information on the context of care and family of elderly caregivers, São Carlos, São Paulo, Brazil, 2014

\begin{tabular}{|c|c|c|c|c|}
\hline Variables & Categories & $\%$ & Mean & $(95 \% \mathrm{CI})$ \\
\hline APGAR family result & & & 17.06 & $(16.57-17.56)$ \\
\hline \multirow[t]{3}{*}{ Family Functionality } & Good family function & 85.0 & & \\
\hline & Moderate family dysfunction & 7.6 & & \\
\hline & High family dysfunction & 7.4 & & \\
\hline \multirow[t]{5}{*}{ Relationship of the elderly } & Spouse & 85.0 & & \\
\hline & Father/mother & 7.3 & & \\
\hline & Father-in-law/mother-in-law & 7.3 & & \\
\hline & Brother/sister & 3.8 & & \\
\hline & Others & 1.8 & & \\
\hline People in the house & Good family function & & 3.02 & $(2.88-3.16)$ \\
\hline Number of children & & & 4.05 & $(3.75-4.35)$ \\
\hline \multirow[t]{4}{*}{ Time of care (years) } & & & 9.96 & $(8.55-11.36)$ \\
\hline & $\leq 10$ years & 46.3 & & \\
\hline & $>10$ years & 50.7 & & \\
\hline & Missing & 2.9 & & \\
\hline Hours of care per day & & & 6.13 & $(5.61-6.65)$ \\
\hline \multirow[t]{3}{*}{ APGAR family result } & Up to 8 & 74.5 & & \\
\hline & More than 8 & 22.9 & & \\
\hline & Missing & 2.6 & & \\
\hline
\end{tabular}

Note: $95 \%$ Cl: $95 \%$ Confidence Interval; $n=341$.

The frailty levels showed collinearity with age $(r=.197 ; p<0.01)$, schooling $(r=.108 ; p=0.046)$, family income $(r=-.202 ; p<0.01)$, number of children $(r=.192 ; p<0.01)$, family APGAR $(r=.113 ; p=0.038)$, total of morbidity $(r=, 180 ; p<0.01)$ and total of medications $(r=.185 ; p<0.01)$.

Additional results showed that living with spouse $(O R=0.44$, $\mathrm{Cl}=0.19-0.99)$ and having children $(\mathrm{OR}=0.59 ; \mathrm{Cl}=0.35-1.0)$ had a protective effect on the feelings of loneliness, independent of other variables. 
Table 3 - Profile of elderly caregivers regarding frailty, loneliness and depressive symptoms, São Carlos, São Paulo, Brazil, 2014

\begin{tabular}{lll}
\hline Variables & Categories & $\%$ \\
\hline Frailty & Non-rail & 22.9 \\
& Pre-frail & 56.3 \\
Frailty criteria & Frail & 20.8 \\
& Weight loss & 21.7 \\
& Fatigue & 24.3 \\
& Weakness & 34.6 \\
& Slowness & 15.2 \\
Loneliness feeling & Physical inactivity & 54.3 \\
& Yes & 23.8 \\
GDS results & No & 76.2 \\
& No depressive symptoms & 70.4 \\
& Depressive symptoms & 29.6 \\
\hline
\end{tabular}

Note: GDS: Geriatric Depression Scale; $n=341$.

Table 4 - Univariate regression between levels of frailty, feeling of loneliness and depressive symptoms in elderly caregivers, São Carlos, São Paulo, Brazil, 2014

\begin{tabular}{|c|c|c|c|c|c|c|}
\hline \multirow{2}{*}{ Variables } & \multicolumn{2}{|c|}{ Pre-frailty } & \multirow{2}{*}{$\underset{\text { value }}{p}$} & \multicolumn{2}{|c|}{ Frailty } & \multirow{2}{*}{$\begin{array}{c}p \\
\text { value }\end{array}$} \\
\hline & OR & $95 \% \mathrm{Cl}$ & & OR & $95 \% \mathrm{Cl}$ & \\
\hline Without loneliness feeling (ref) & 1.0 & - & - & 1.0 & - & - \\
\hline With loneliness feeling & 3.33 & $1.54-7.40$ & $.003^{*}$ & 3.43 & $1.40-8.40$ & $.007^{*}$ \\
\hline No depressive symptoms (ref) & 1.0 & - & - & 1.0 & - & - \\
\hline Depressive symptoms & 3.40 & $1.59-7.26$ & $.002^{*}$ & 6.65 & $2.88-15.37$ & $<.001 *$ \\
\hline
\end{tabular}

Note: OR: Odds Ratio; $95 \%$ Cl: $95 \%$ Confidence Interval; ${ }^{*} p \leq 0.05$. Ref: reference variable; pre-frailty $(n=192 / 251)$; frailty $(n=71 / 135)$.

Table 5 - Multiple regression between levels of frailty, feeling of loneliness and depressive symptoms in elderly caregivers, São Carlos, São Paulo, Brazil, 2014

\begin{tabular}{|c|c|c|c|c|c|c|}
\hline \multirow{2}{*}{ Variables } & \multicolumn{2}{|c|}{ Pre-frailty } & \multirow{2}{*}{$\begin{array}{c}p \\
\text { value }\end{array}$} & \multicolumn{2}{|c|}{ Frailty } & \multirow{2}{*}{$\begin{array}{c}p \\
\text { value }\end{array}$} \\
\hline & OR & $95 \% \mathrm{Cl}$ & & OR & $95 \% \mathrm{Cl}$ & \\
\hline Without feeling of loneliness (ref) & 1.0 & - & - & 1.0 & - & - \\
\hline With feeling of loneliness & 2.58 & $1.04-6.37$ & $.040^{*}$ & 4.60 & $1.40-14.0$ & $.012^{*}$ \\
\hline No depressive symptoms (ref) & 1.0 & - & - & 1.0 & - & - \\
\hline With depressive symptoms & 2.31 & $0.96-5.57$ & .061 & 3.42 & $1.19-9.79$ & $.022^{*}$ \\
\hline Female (ref) & 1.0 & - & - & 1.0 & - & - \\
\hline Male & 0.73 & $0.36-1.48$ & .397 & 0.89 & $0.32-2.47$ & .826 \\
\hline Age 60-69 years (ref) & 1.0 & - & - & 1.0 & - & - \\
\hline Age $\geq 70$ years & 2.62 & $1.33-5.17$ & $.005^{*}$ & 3.89 & $1.50-10.13$ & $.005^{*}$ \\
\hline Schooling $>4$ years (ref) & 1.0 & - & - & 1.0 & - & - \\
\hline Schooling ( $\leq 4$ years) & 0.48 & $0.21-1.09$ & .081 & 1.05 & $0.24-4.57$ & .938 \\
\hline Income (continuous) & 1.00 & $0.98-1.0$ & $.028^{*}$ & 1.00 & $0.99-1.00$ & 1.0 \\
\hline Number of children (continuous) & 1.02 & $0.90-1.17$ & .679 & 1.15 & $0.99-1.33$ & .061 \\
\hline APGAR without dysfunction (ref) & 1.0 & - & - & 1.0 & - & - \\
\hline APGAR with family dysfunction & 1.18 & $0.42-3.28$ & .741 & 1.78 & $0.47-6.70$ & .388 \\
\hline Absence of multimorbity (ref) & 1.0 & - & - & 1.0 & - & - \\
\hline With multimorbity & 0.89 & $0.34-2.34$ & .828 & 0.54 & $0.11-3.75$ & .630 \\
\hline Absence of polypharmacy (ref) & 1.0 & - & - & 1.0 & - & - \\
\hline Polypharmacy & 1.99 & $0.86-4.61$ & .106 & 4.69 & $1.67-12.95$ & $.003^{*}$ \\
\hline
\end{tabular}

Note: 95\% Cl: 95\% Confidence Interval; OR: Odds Ratio; * $p \leq 0.05$. Ref: reference variable; pre-frailty $(n=192 / 251)$; frailty $(n=71 / 135)$. "Nonfrail" was the reference category.

\section{DISCUSSION}

The present study investigated the association between frailty, loneliness and depressive symptoms in elderly caregivers of other elderly people. It has been found that elderly caregivers feel alone. Those with depressive symptoms are more likely to be frail and pre-frail.
The prevalence of frailty in the elderly caregivers of the sample was $20.8 \%$, higher than a study carried out with elderly caregivers inserted in a context of high social vulnerability $(10 \%)^{(16)}$ and the study conducted in an outpatient clinic (18\%) $)^{(17)}$. A systematic Brazilian elderly can vary from $7 \%$ to $59 \%$, depending on the place of study, the inclusion criteria of the participants and the size of the sample ${ }^{(26)}$, which makes it difficult to compare of data.

In addition, the frailty showed collinearity with age. A systematic review was performed with the objective of identifying the sociodemographic factors associated with the syndrome. The authors found a positive relationship between frailty and age, noting that the elderly with more advanced ages were more likely to be pre-frail and frail, occurring more significantly after age $80^{(27)}$. In literature, there was a research that describes this association due to changes at the cellular and systematic level that are triggered by oxidative stress over the years ${ }^{(27-28)}$. A survey of 686 non-institutionalized elderly people found that the participants who were 80 years of age or older presented a higher percentage of frailty $(68.9 \%)$ when compared to younger (60 to 79 years) (34.0\%). The results also showed that after the multivariate regression analysis, the variables: age over 80 years, female gender, low schooling, presence of a caregiver, fall in the last year, Diabetes Mellitus, cardiovascular disease, osteoarticular disease remained associated with frailty in this population ${ }^{(29)}$.

The feeling of loneliness can be considered the result of an affective-cognitive experience in which there is a discrepancy between what is possessed and what is desired in quantitative and qualitative terms of social and affective support ${ }^{(30)}$. With the increase in the number of elderly caregivers in the population, this is a variable that has been highlighted as a challenge to health professionals because of their wide complexity and impact on quality of life and health.

In literature, studies have shown that feeling alone is associated with physical, cognitive decline ${ }^{(31)}$, low participation in social activities ${ }^{(32)}$ and increased risk of malnutrireview has shown that the prevalence of the syndrome in the tion $^{(33)}$, and mortality among the elderly ${ }^{(34)}$. In China, in a crosssectional study, researchers assessed in 14,072 elderly people whether loneliness would predict mortality and whether the effect of loneliness on mortality could be explained by social, physical, emotional, and functional health behaviors. As results, they found that people who felt only had a higher chance of 
dying in subsequent years, even after controlling for sociodemographic variables and social relationships. Researchers also point out that the feeling of loneliness is part of a set of worse levels of physical, cognitive and emotional health and a network of weakened social contacts ${ }^{(35)}$.

The hypothesis that the feeling of loneliness increases the chances of the elderly being pre-frail or frail is supported by the data found in this study and is in line with previous research ${ }^{(13,36-37)}$. Researchers suggest the existence of two potential mechanisms that link loneliness to the frailty syndrome: low physical activity and precarious feeding. They say that the elderly alone are more likely to be physically inactive and may not feed properly, which contributes to sarcopenia and, consequently, to physical frailty. Lonely elderly are more likely to be sarcopenic and with functional decline ${ }^{(13)}$. In addition, authors say that older people who feel alone are less encouraged to join groups, interact with other people and engage in physical activity. Poor social interaction may have an adverse impact on the health of the elderly as a result of lower exposure to health-inducing behaviors and lower psychological well-being ${ }^{(37)}$. This may negatively influence both the psychological dimension of the individual and the physical dimension and predispose the individual to the development of said syndrome ${ }^{(38)}$.

In England, 2,817 elderly participants in the English Longitudinal Study of Aging (ELSA) compose a research sample to investigate whether loneliness is associated with the progression of frailty. The results showed that loneliness was associated with a greater risk of the elderly becoming physically frail or pre-frail during the four years of follow-up. Lonely elders were 74 percent more likely to become pre-frail and 85 percent more likely to become frail. The authors concluded that older people experiencing loneliness are at greater risk of becoming frail ${ }^{(13)}$.

A qualitative research that assessed the experience of loneliness among frail elderly emphasized three themes that emerged from the analysis of content, being: "Being in a Bubble"that illustrated the experience of living excluded from the social environment; "Barriers" has been interpreted as coping with physical, psychological, and social barriers to overcoming loneliness; and "Despair" that revealed the experience of not being able to overcome the barriers, including the vision of loneliness as a constant state ${ }^{(39)}$.

Regarding the feeling of loneliness in caregivers, researchers conducted a study in Europe with 3,633 people providing informal care to a family member aged 50 or over. The authors identified that caregivers present a greater feeling of loneliness when compared with non-caregivers. They concluded that this is due to the lesser availability of the caregiver for social activities ${ }^{(40)}$. Elderly individuals without significant social interaction and lonely ones under acute stress may present alterations in the neuroendocrine activity and greater inflammatory state, factors that are present in the installation of the frailty syndrome ${ }^{(36)}$.

In Brazil, the theme of loneliness among caregivers, although little explored, appears in the studies as a descriptor that represents the negative consequences of high levels of care overload, stress and depressive symptoms present in the caregiver's care routine ${ }^{(41)}$. Literature shows a positive relationship between elderly people with high levels of loneliness and depression as described in a survey carried out in China with 320 individuals, aged over 60 years, identifying a positive correlation between these variables ${ }^{(42)}$. Some authors describe that individuals with high levels of loneliness present high dissatisfaction with life and more negative emotions. Thus, loneliness may be a predictor of depressive symptoms in the elderly ${ }^{(42-43)}$.

A cross-sectional study developed with Dutch elderly verified through linear regression that loneliness was a determining factor in the severity of depressive symptoms during the two years of follow up of the research ${ }^{(44)}$. Other recent research conducted with Israeli participants over 50 years of age also identified that high levels of loneliness were predictors of depressive symptoms $(p<0.001)^{(12)}$.

The relationship between depression and frailty in the elderly is generally described in literature. A recent systematic review and meta-analysis analyzed 24 studies and found that the prevalence of depression in the frail elderly is around $40 \%$, with a similar result for frailty in the elderly with depression. Frail elders are approximately four times more likely to have depression than non-frail older people. The odds are similar for older people with depression to be frail compared to older people without depression. Results of cross-sectional studies confirmed the finding $\mathrm{s}^{(45)}$.

In Japan, a cross-sectional study was conducted with 3,025 community-dwelling elderly ( $\geq 65$ years), with the objective of determining if frailty would be a predictor of depressive symptoms. As a result, $7.5 \%$ of the elderly developed depressive symptoms during follow-up. Frailty was an independent predictor of depressive symptoms ( $\mathrm{OR}=1.86,95 \% \mathrm{Cl} 1.05-3.28, \mathrm{p}=0.03$ ) (14). Another study conducted in Singapore with 1,827 individuals ( mean $=65.9$ years; $S D=7.2$ ) aimed at analyzing the transverse and longitudinal relationships between physical frailty and depressive symptoms at baseline and at follow-up for four years. At the baseline, $11.4 \%$ had depressive symptoms, $32.4 \%$ were pre-frail and $2.5 \%$ were frail; $(\mathrm{OR}=1.69,95 \% \mathrm{Cl}=1.23-2.33)$ and frailty $(\mathrm{OR}=2.36,95 \% \mathrm{Cl}=1.08-5.15)$ were significantly associated with the symptoms depressive. In the longitudinal analysis, the relationship between depressive symptoms and frailty remained significant (pre-frailty: $\mathrm{OR}=1.86,95 \% \mathrm{Cl}=1.08-3.20$, frailty: $\mathrm{OR}=$ $3.09,95 \% \mathrm{Cl}=1.12-8.50$ ). Authors concluded that frailty can be considered a predictor of depressive symptoms ${ }^{(15)}$.

Studies also show that high levels of frailty in the elderly may predict non-remission of depression over time, that is, being frail is associated with persistent depression and an increase in depressive symptoms ${ }^{(46)}$.

The present research corroborates with these data, but the sample assessed is composed specifically of elderly caregivers. Due to the demands of care and emotional overload from caring, caregivers may experience more depressive symptoms and depression.

A meta-analysis of 84 studies that assessed the difference between caregivers and non-caregivers found that the caregiver group was more stressed, depressed, and had worse subjective well-being, physical health, and self-efficacy. Differences were greater for the caregiver's spouse when compared to an adult child $^{(47)}$. In addition, in another meta-analysis of 168 studies, the authors identified that caregiver spouses presented higher levels of depression than their children and son/daughter-in-law ${ }^{(48)}$. With regard to depression in the elderly caregiver, a literature review of 17 studies found that from investigations comparing elderly caregivers and non-caregivers, most reported that the former had significantly more depressive symptoms ${ }^{(49)}$. 
Therefore, the relationship between frailty and depressive symptoms in this specific group may be stronger and cause more damage than in the elderly in general, evidencing the need for interventions. It is worth emphasizing that due to the relationship between the two conditions, interventions aimed at improving one of the variables can improve the other and even prevent the emergence of the same over the years.

In the context of care, interventions aimed at elderly dyad caregiver - elderly care recipient may be an alternative to be considered. One study found that the greater frailty of an elderly person predicts greater frailty in their spouse over the years, and so does depression ${ }^{(50)}$. Considering that most elderly caregivers are spouses, prevention and control of these variables can benefit both caregivers and caregivers. Therefore, encouraging and offering opportunities for elderly couples to get socially involved, seek social support and practice physical activities is important ${ }^{(50)}$, since they can bring benefits for both conditions and for both elderly people.

\section{Study limitations}

It is a cross-sectional study carried out with a specific sample of elderly caregivers. Given this, the data cannot be generalized. In addition, it is not possible to establish a cause and effect relationship.

\section{Contribuições to Nursing, Health or Public Policy}

Public policies for elderly care can be reformulated taking into consideration that the number of elderly caregivers of other elderly people tends to increase exponentially in Brazil. In addition, the findings of the present study serve as a warning to health professionals, particularly nurses, about the need for early identification of the frailty syndrome and its relation to loneliness and depressive symptoms. In the possession of this information, an in-depth evaluation of the elderly encompassing these variables can be carried out with a view to the implementation of an individualized care plan, aiming at delaying the onset or reversion of such syndrome, besides intervening in associated factors.

The results of the present study contributed to minimize the gap in the scientific literature regarding the relationship between frailty, depressive symptoms and loneliness of elderly caregivers. Consolidation of nursing as science requires the determination and delimitation of its object of study and the factors that exert an influence on this object. In addition, with the results obtained, there will be a scientific subsidy for nurses to plan their care for elderly caregivers. That is, the articulation between theory and practice is fundamental for this planning, from the moment it scientifically bases the actions of nursing.

\section{CONCLUSION}

Lonely caregivers who have depressive symptoms are more likely to be frail and pre-frail. Loneliness, compared to depressive symptoms, showed a stronger association with frailty. Therefore, it is imperative for health professionals to provide adequate support to elderly caregivers, especially those with depressive symptoms and feelings of loneliness. Actions aimed at increasing the emotional support and social support that these elderly caregivers receive, such as support groups, may be helpful in preventing the syndrome. In addition, these elderly caregivers must be followed up by the health team in order for their demands to be met.

\section{FUNDING}

This study was funded by the National Council for Scientific and Technological Development (CNPq - 304067/2015-6) and by the Foundation for Research Support of the State of São Paulo (Fapesp - 2017/04129-9).

\section{REFERENCES}

1. Reis LA, Trad LAB. Suporte familiar ao idoso com comprometimento da funcionalidade: a perspectiva da família. Rev Psicol Teor Prat [Internet]. 2015[cited 2018 Jan 22];17(3):28-41. Available from: http://pepsic.bvsalud.org/pdf/ptp/v17n3/03.pdf

2. World Health Organization. Global strategy and action plan on ageing and health [Internet]. Geneva: WHO; 2017 [cited 2018 Jun 19]. Available from: http://www.who.int/ageing/WHO-GSAP-2017.pdf?ua=1

3. Lima-Costa MF, Peixoto SV, Malta DC, Szwarcwald CL, Manbrini JVM. Informal and paid care for Brazilian older adults (National Health Survey, 2013). Rev Saude Publica. 2017;51(Supl 1:6s):1-9. doi: 10.1590/s1518-8787.2017051000013

4. Oliveira NA, Souza EN, Luchesi BM, Inouye K, Pavarini SCI. Stress and optimism of elderlies who are caregivers for elderlies and live with children. Rev Bras Enferm. 2017;70(4):697-703. doi: 10.1590/0034-7167-2017-0088

5. Sarvimäki A, Stenbock-Hult B, Sundell E, Oesch-Börman C. The vulnerability of family caregivers in relation to vulnerability as understood by nurses. Scand J Caring Sci. 2017; 31:112-9. doi: 10.1111/scs.12325

6. Hiel L, Beenackers MA, Renders CM, Robroek SJW, Burdorf A, Croezen S. Providing personal informal care to older European adults: Should we care about the caregivers' health?. Prev Med. 2015;70:64-8. doi: 10.1016/j.ypmed.2014.10.028

7. Flesch LD, Batistoni SST, Neri AL, Cachioni M. Psychological aspects of the quality of life of caregivers of the elderly: an integrative review. Geriatr Gerontol Aging. 2017;11(3):138-49. doi: 10.5327/Z2447-211520171700041

8. Holwerda TJ, van Tilburg TG, Deeg DJ, Schutter N, Van R, Dekker J, et al. Impact of loneliness and depression on mortality: results from the Longitudinal Ageing Study Amsterdam. Br J Psychiatr. 2016;209(2):127-34. doi: 10.1192/bjp.bp.115.168005

9. Vasileiou K, Barnett J, Barreto M, Vines J, Atkinson M, Lawson S, et al. Experiences of loneliness associated with being an informal caregiver: a qualitative investigation. Front Psychol. 2017;8:585. doi: 10.3389/fpsyg.2017.00585 
Elderly caregivers of the elderly: frailty, loneliness and depressive symptoms Santos-Orlandi AA, Brigolla AG, Ottaviani AC, Luchesi BM, Souza EM, Moura FG, et al.

10. Holwerda TJ, Deeg DJH, Beekman ATF, van Tilburg TG, Stek ML, Jonker C, et al. Feelings of loneliness, but not social isolation predict dementia onset: results from the Amsterdam Study of the Elderly (AMSTEL). J Neurol Neurosurg Psychiatr. 2014;85:135-42. doi: 10.1136/ jnnp-2012-302755

11. Jaremka LM, Andridge RR, Fagundes CP, Alfano CM, Povoski SP, Lipari AM, et al. Pain, depression, and fatigue: loneliness as a longitudinal risk factor. Health Psychol. 2014;33(9):948-57. doi: 10.1037/a0034012

12. Bodner E, Bergman YS. Loneliness and depressive symptoms among older adults: the moderating role of subjective life expectancy. Psychiatr Res. 2016;237:78-82. doi: 10.1016/j.psychres.2016.01.074

13. Gale CR, Westbury L, Cooper C. Social isolation and loneliness as risk factors for the progression of frailty: the English Longitudinal Study of Ageing. Age Ageing. 2017;0:1-6. doi: 10.1093/ageing/afx188

14. Makizako H, Shimada H, Doi T, Yoshida D, Ana Y, Tsutsumimoto K, et al. Physical frailty predicts incident depressive symptoms in elderly people: prospective findings from the Obu Study of Health Promotion for the Elderly. J Am Med Dir Assoc. 2015;16(3):194-9. doi: 10.1016/j.jamda.2014.08.017

15. Feng L, Nyunt MSZ, Feng L, Yap KB, Ng TP. Frailty predicts new and persistent depressive symptoms among community-dwelling older adults: findings from Singapore Longitudinal Aging Study. J Am Med Dir Assoc. 2014;15(1):76.e7-76.e12. doi: 10.1016/j.jamda.2013.10.001

16. Santos-Orlandi AA, Brito TRP, Ottaviani AC, Rossetti ES, Zazzetta MS, Pavarini SCI. Elderly who take care of elderly: a study on the Frailty Syndrome. Rev Bras Enferm. 2017;70(7):822-9. doi: 10.1590/0034-7167-2016-0474

17. Tomomitsu MRS, Lemos ND, Perracini M. Prevalência e fatores associados à fragilidade em cuidadores idosos. Geriatr Gerontol [Internet]. 2010 [cited 2018 Jun 19];4(1):3-12. Available from: http://ggaging.com/export-pdf/292/v4n1a02.pdf

18. Ministério da Saúde (BR). Portaria no 2.528 de 19 de outubro de 2006. Aprova a Política Nacional de Saúde da Pessoa Idosa. [Internet]. Available from: http://bvsms.saude.gov.br/bvs/saudelegis/gm/2006/prt2528_19_10_2006.html

19. Katz S, Ford AB, Moskowitz RW, Jackson BA, Jaffe MW. Studies of illness in the aged: the index of ADL: a standardized measure of biological and psychosocial function. JAMA. 1963;185(12):914-9. doi: 10.1001/jama.1963.03060120024016

20. Lawton MP, Brody EM. Assessment of older people: self-maintaining and instrumental activities of daily living]. Gerontol. 1969;9:179-86. doi: 10.1093/geront/9.3_Part_1.179

21. Fried LP, Tangen CM, Waltson J, Newman AB, Hirshc C, Gottdiener J, et al. Frailty in older adults: evidence for a phenotype. J Gerontol A Biol Sci Med Sci. 2001;56(3):M146-56. doi: 10.1093/gerona/56.3.M146

22. Duarte YAO. Família: rede de suporte ou fator estressor: a ótica de idosos e cuidadores familiares. [Tese]. São Paulo (SP): Escola de Enfermagem, Universidade de São Paulo; 2001. 196f.

23. Almeida O, Almeida SA. Confiabilidade da versão brasileira da Escala de Depressão em Geriatria (GDS) versão reduzida. Arq Neuropsiquiatr [Internet]. 1999 [cited 2018 Jan 18];57(2):421-6. Available from: http://www.scielo.br/pdf/anp/v57n2B/1446.pdf

24. Dias FL, Teixeira AL, Guimarães HC, Barbosa MT, Resende EP, Beato RG, et al. Accuracy of the 15-item Geriatric Depression Scale (GDS-15) in a community-dwelling oldest-old sample: the Pietà Study. Trends Psychiatry Psychother. 2017;39(4):276-279. doi: 10.1590/2237-6089-2017-0046

25. Sartore ACA, Gross SAA. Escala de Esperança de Herth - instrumento adaptado e validado para a língua portuguesa. Rev Esc Enferm USP [Internet]. 2008 [cited 2018 Jan 18];42:227-32. Available from: http://www.scielo.br/pdf/reeusp/v42n2/a02.pdf

26. Pinto Jr EP, Marques CG, Siebra e Silva AV, Guimarães MAP, Pedreira RBS, Silva MGC. Prevalência e fatores associados ao fenótipo da fragilidade em idosos brasileiros: uma revisão de literatura. Rev Kairós Gerontol [Internet]. 2015 [cited 2018 Jun 19]; 18(3):353-66. Available from: https://revistas.pucsp.br/index.php/kairos/article/viewFile/28125/19779

27. Mello AC, Engstrom EM, Alves LC. Health-related and socio-demographic factors associated with frailty in the elderly: a systematic literature review.Cad Saúde Pública. 2014;30(6):1143-68. doi: 10.1590/0102-311X00148213

28. Mulero J, Zafrilla P, Martinez-Cacha A. Oxidative stress, frailty and cognitive decline. J Nutr Health Aging. 2011;15(9):756-60. doi: 10.1007/ s12603-011-0130-5

29. Carneiro JA, Ramos GCF, Barbosa ATF, Mendonça JMG, Costa FM, Caldeira AP. Prevalence and factors associated with frailty in noninstitucionalized older adults. Rev Bras Enferm. 2016;69(3):408-15. doi: http://dx.doi.org/10.1590/0034-7167.2016690304i

30. Masi CM, Chen HY, Hawkley LC, Cacioppo JT. A meta-analysis of interventions to reduce loneliness. Pers Soc Psychol Rev. 2011;15(3):1-66. doi: $10.1177 / 1088868310377394$

31. Luo Y, Hawkley LC, Waite LJ, Cacioppo JT. Loneliness, health, and mortality in old age: a national longitudinal study. Soc Sci Med. 2012;74:907-14. doi: 10.1016/j.socscimed.2011.11.028

32. Niedzwiedz CL, Richardson EA, Tunstall H, Shortt NK, Mitchell RJ, Pearce JR. The relationship between wealth and loneliness among older people across Europe: Is social participation protective? Prev Med. 2016;91:24-31. doi: 10.1016/j.ypmed.2016.07.016

33. Boulos C, Salameh P, Barberger-Gateau P. Social isolation and risk for malnutrition among older people. Geriatr Gerontol Int. 2016;17(2):28694. Available from: http://onlinelibrary.wiley.com/doi/10.1111/ggi.12711/epdf

34. Gerst-Emerson K. Loneliness among very old mexican americans: findings from the hispanic established populations epidemiologic studies of the elderly. Arch Gerontol Geriatr. 2014;59(1):145-9. doi: 10.1016/j.archger.2014.01.007

35. Luo Y, Waite J. Loneliness and mortality among older adults in China. J Geront B Pshycol Sci Soc Sci. 2014;69(4):633-45. doi: 10.1093/geronb/gbu007 
36. Herrera-Badilla A, Navarrete-Reyes A, Amieva H, Avila-Funes JA. Loneliness is associated with frailty in community-dwelling elderly adults. J Am Geriatr Soc. 2015;63:607-9. doi: https://doi.org/10.1111/jgs.13308

37. Hoogendijk EO, Suanet B, Dent E, Deeg DJ, Aartsen MJ. [Adverse effects of frailty on social functioning in older adults: results from the Longitudinal Aging Study Amsterdam. Maturitas. 2016;83:45-50. doi: 10.1016/j.maturitas.2015.09.002

38. Lenardt ME, Carneiro NHK, Binotto MA, Setoguchi LS, Cechinel C. The relationship between physical frailty and sociodemographic and clinical characteristics of elderly. Esc Anna Nery. 2015;19(4):585-92. doi: 10.5935/1414-8145.20150078

39. Taube E, Jakobsson U, Midlov P, Kristensson J. Being in a Bubble: the experience of loneliness among frail older people. J Adv Nurs. 2015;72(3):631-40. doi: 10.1111/jan.12853

40. Wagner M, Brandt M. Loneliness among informal caregivers aged 50+ in Europe. In: A Borsch-Supan, T Kneip, H Litwin, M Myck, G. Weber (Eds.). Ageing in Europe: Supporting policies for an inclusive society (pp. 179-188). Berlin, Germany: De Gruyter, 2015. Available from: https://www.degruyter.com/downloadpdf/books/9783110444414/9783110444414-018/9783110444414-018.pdf

41. Souza EN, Oliveira NA, Luchesi BM, Gratão ACM, Orlandi FS, Pavarini SCl. Relationship between hope and spirituality of elderly caregivers. Texto Contexto Enferm. 2017;26(3):e6780015. doi: 10.1590/0104-07072017006780015

42. Liu L, Gou Z, Zuo J. Social support mediates loneliness and depression in elderly people. J Health Psychol. 2016;21(5):750-8. doi: $10.1177 / 1359105314536941$

43. Hansen NB, Harrison B, Fambro S, Bodnar S, Heckman TG, Sikkema KJ. The structure of coping among older adults living with HIV/AIDS and depressive symptoms. J Health Psychol. 2013;18(2):198-211. doi: 10.1177/1359105312440299

44. Holvast F, Burger H, Waal MMW, van Marwijk HWJ, Comijs HC, Verhaak PFM. Loneliness is associated with poor prognosis in late-life depression: longitudinal analysis of the Netherlands study of depression in older persons. J Affect Dis. 2015;185:1-7. doi: 10.1016/j. jad.2015.06.036

45. Soysal P, Veronese N, Thompson T, Kahl KG, Fernandes BS, Prina AM, et al. Relationship between depression and frailty in older adults: a systematic review and meta-analysis. Ageing Res Rev. 2017;36:78-87. doi: 10.1016/j.arr.2017.03.005

46. Collard RM, Arts MHL, Schene AH, Naarding P, Voshaar O, Comijs HC. The impact of frailty on depressive disorder in later life: findings from the Netherlands Study of depression in older persons. Eur Psychiatry. 2017;43:66-72. doi: 10.1016/j.eurpsy.2017.01.003

47. Pinquart $M$, Sorensen S. Differences between caregivers and noncaregivers in psychological health and physical health: a meta-analysis. Psychol Aging. 2003;18(2):250-67. doi: 10.1037/0882-7974.18.2.250

48. Pinquart $\mathrm{M}$, Sorensen S. Spouses, adult children, and children-in-law as caregivers of older adults: a meta-analytic comparison. Psychol Aging. 2011;26(1):1-14. doi: 10.1037/a0021863

49. Luchesi BM, Degani GC, Brigola AG, Pavarini SCl, Marques S. Evaluation of depressive symptoms in older caregivers. Arch Clin Psych. 2015;42(2):45-51. doi: 10.1590/0101-60830000000047

50. Monin J, Doyle M, Levy B, Schulz R, Fried T, Kershaw T. Spousal associations between frailty and depressive symptoms: longitudinal findings from the Cardiovascular Health Study. J Am Geriatr Soc. 2016;64:824-30. doi: 10.1111/jgs.14023 